\title{
7 Iconism and characterism of Polybius Rhetor, Trypho and Publius Rutilius Lupus Rhetor
}

Physiognomy, as is well-known, is a peculiar branch of philosophy that claims to infer moral and behavioral characteristics from physical characteristics. It is commonly thought that physiognomy was invented by Pythagoras or, in the medical field, by the famous Hippocrates. ${ }^{1}$ However, physiognomy reached its decisive moment of theoretical reflection with Aristotle.

This contribution, which results from a broader, long-term work that is in progress, seeks to add to the set of well-known treatises on Greek physiognomy a number of late Byzantine texts written by authors such as Daretes of Phrygia, ${ }^{2}$ John Malalas, ${ }^{3}$ Tzetzes Grammaticus, ${ }^{4}$ and Isaac Porphyrogenitus. ${ }^{5}$

1 Greek translations are mine unless otherwise indicated. For an in-depth study of the topics discussed in this chapter, see Cianci 2014.

2 Another person with the same name Daretes, who is mentioned in the Iliad (5.9-12), is presented as a first-hand witness to the Trojan War in Photius (Bibliotheca 190.147a). Antipater of Acanthus refers to a Daretes who wrote the Iliad before Homer, was the mentor of Hector, and made him promise not to kill Achilles. This story is included within the New History of Ptolomaeus Chennus or Epheterion, handed down to us by Photius. Ptolomaeus Chennus mentions Antipater and the two authors as important for dating Daretes's writings. It is clear that for Daretes there is at least one Hellenistic precedent, since Ptolomaeus Chennus was from the first century AD (cf. Philostratus, Life of Sophists, 2.607), and Antipater, some time later, has been recalled as the preceptor of Caracalla. Erroneously, Daretes' work has been attributed to the 6th century BC.

3 Malalas lived between 490 and $570 \mathrm{AD}$. He was a Byzantine rhetorician and historian; the name "Malalas" means "rhetorician" in Syriac. He was educated in Antioch and probably worked there as a bureaucrat in his early years. Sometime between 530 and 540 he moved to Constantinople. The hypothesis proposed by Haury 1900: 337-356, who identified him with John III Scholasticus, should be rejected. Malalas's Chronographia is now available in Thurn's edition (2000). In chapter 5 Malalas deals with portraits of Homeric heroes (except Polyxena and Palamedes) and in chap. 7 of Roman emperors. It should be noted that in chapter 4, where the story of the Minotaur is described, two important descriptions of mythological characters occur, that of Phaedra and that of Hippolytus 4. In this chapter Pasiphaes, Ariadne and Theseus are also mentioned, but there are no descriptions of them.

4 Born in Constantinople in 1100 and died between 1180 and 1185. Georgian on his mother's side. His greatest work is the "Book of Histories", then titled Chiliades by the first editor (XVI sec.). It consists of a miscellaneous work of mythology, history and literature. A large philological work is represented by the Exegesis Iliadis, which lines up with other commentaries to Homer authored by Tzetzes, such as Allegoriae Iliadis, Allegoriae Odysseae, Antehomerica, Homerica and Posthomerica. His commentaries to Hesiod, Aristophanes, Licophron, Nicandrus and Porphyry are also important.

5 Biography still uncertain. Probably born in 1053. Under the Comneni dynasty Isaac was a common name, borne for example by the son of Emperor Manuel, or by the brother of Alexis I, but there is no trace of literary activity among any of these, nor of the appellative "Porphirogenitus" in the sources. See De Characteribus (Hinck 1873). 
The first of these texts to be considered here is that of Dictys of Crete, ${ }^{6}$ which has survived, with the exception of some papyrus fragments, in a Latin translation that does not feature physiognomic descriptions. Like Dictys, also Daretes of Phrygia survives in a Latin translation which does however include portraits of mythological characters. All the other authors mentioned write in Greek. These texts are different from normal physiognomic descriptions because they do not refer to the stereotyped however real, physical and moral peculiarities of human beings, but rather to characters that are usually - but not exclusively - drawn from the Homeric poems. The specific interest of these texts lies in the fact that they combine two apparently distant disciplines: physiognomy, conceptualized as a philosophical topic, and mythology, which involves the cultural and creative environment. Mythology has the advantage of bestowing the power of antonomasia - the substitution of an epithet for an actual name - in a variety of situations from everyday life. It gives a recognizable name to these situations and therefore confers charm on otherwise non-attractive physiognomic cases.

In authors such as Daretes, Malalas, Tzetzes, and Isaac, there are only descriptions of people and descriptions of bodies that we cannot, strictly speaking, call ekphrasis. The rhetorical tradition had precise knowledge of this technique, which was called $\chi \alpha \rho \alpha \kappa \tau \varepsilon \rho$ เ ó$_{\text {, }}$ a term passed down by two Greek rhetoricians, Polybius Rhetor and Trypho, and by a Latin rhetorician, Publius Rutilius Lupus. The dates surrounding Polybius are uncertain, but according to Spengel - in Rhetores Graeci - he lived before Trypho, in the first century BC. Rutilius Lupus was a writer from the age of Tiberius.

Polybius Rhethor, De figuriis, $R h G$, III, 108 Spengel

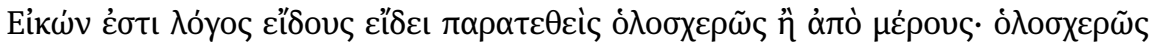

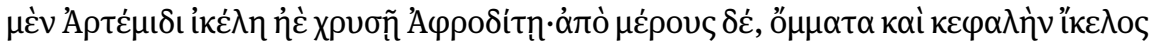

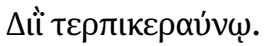

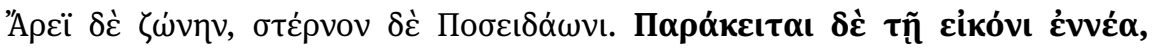

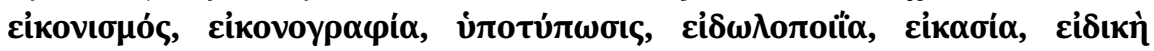
ò

6 Dyctys is the source indicated by Malalas ( $\$ 5$ Thurn, 79.63; 80.68; 89.52; 91.91; 92.72), by his associate Isaac Porphyrogene (p. 80, 21-87, 24 Hinck) and by Tzetzes (Allegoriae 508-744; 786-835 Jacobs) in the physiognomic sections of their works. But in the Latin version of Dictys, Ephemeris belli Troiani from Septimus - an otherwise unknown author - the descriptions of the characters of the Homeric heroes are missing, hence the hypothesis that the portrait gallery was included in the original Greek version which went lost. The edition currently used for Dictys is that of Eisenhut (1973), which revised and corrected the one from 1958. The one from Dederich (1833) and the other one from Meister (1872) are now outdat-

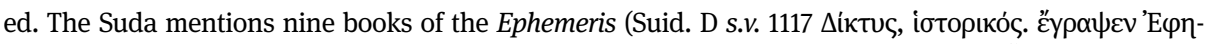

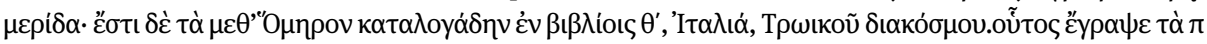

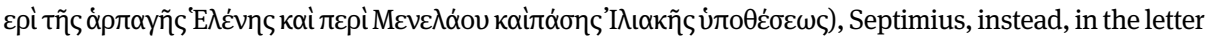
to his friend Aradius Rufinus (1.17-2.4) counts ten books (itaque priorum quinque voluminum ... eundem numerum servavimus, residua de reditu Graecorum quinque in unum redigimus atque ita ad te misimus). 


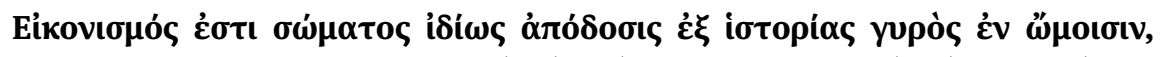

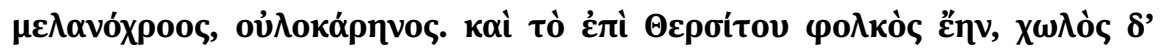

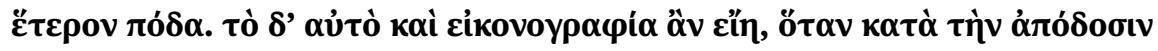

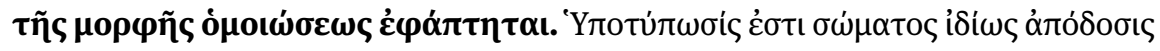

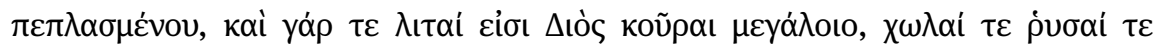

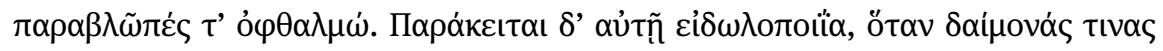

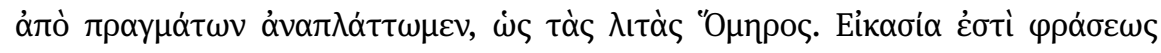

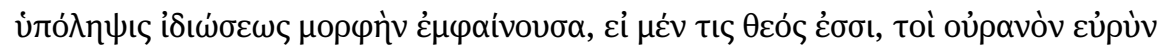

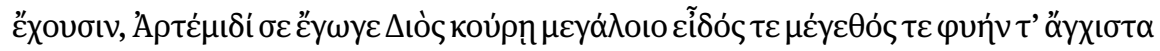

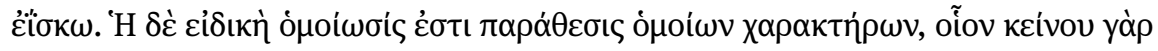

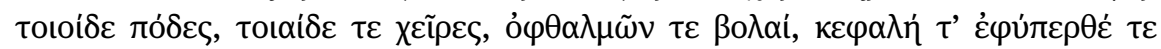

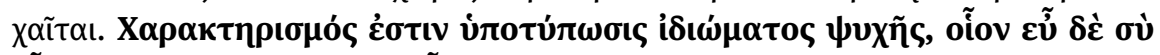

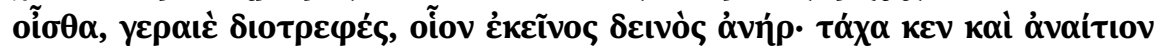

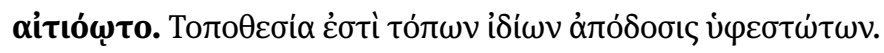

The Eikw'v is a speech about personal characteristics that refers to the deity or person as a whole as well as to individual body parts. In reference to the entire body, it might state, for instance, that someone is "similar to Artemis" or "similar to Aphrodite of gold"; in reference to specific body parts, instead, that someone is "similar to the eyes" or "to the head of Zeus, caster of lightning", "to the hips of Ares" or "similar to the chest of Poseidon". There are nine terms

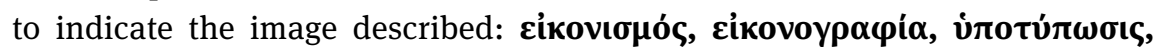

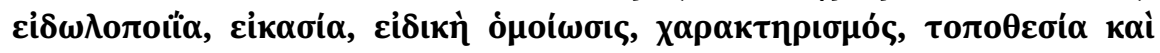

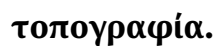

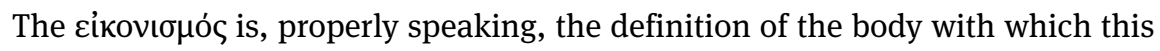

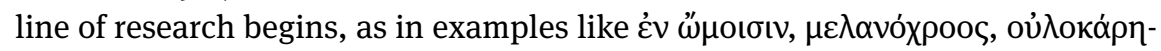
vos and "Thersites had crooked legs; he was lame". This would be the

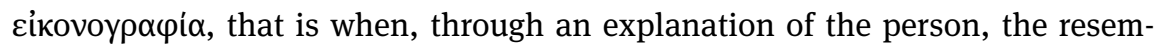
blance is captured [...]; cik $\alpha \sigma i \alpha$ is the typical attribute of distinction, which is

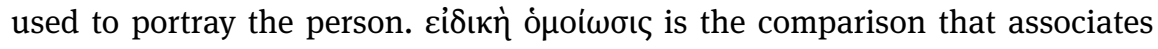

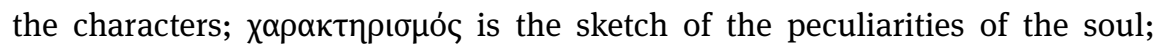

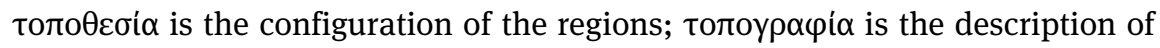
the peculiarities of a place.

From the text of Polybius the rhetorician, the physiognomic descriptions of the portraits can be defined as iconisms, both in terms of the descriptions of the body and also for the characterization of moral qualities.

Trypho Grammaticus, Fragmenta, RhG, III, 201 Spengel

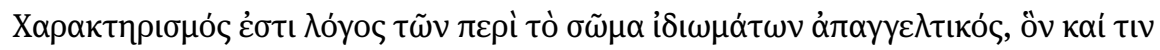

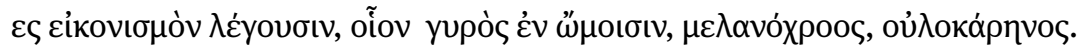


From the text of Trypho, however, it is clear that characterism is also a topic when it comes to peculiarities of the body, what some might call iconicism, referring to Od. 19.246, where Eurybates is described as "round shouldered, dark skinned, curly headed". The difference between the two rhetorical terms, in this case, has been nullified. In a scholion on the Odyssey, this figure is called iconism, following Polybius:

Scholia ad Odyss. ${ }^{\text {vet. } 19.246}$

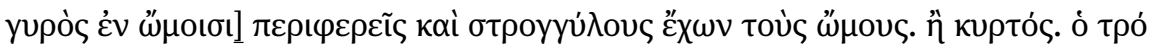

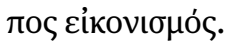

Publius Rutilius Lupus (Rhetores Latini Minores 1863, 16-17), in his work Schemata dianoia et lexeos, thus defines the characterism:

Quem ad modum pictor coloribus figuras describit, sic orator hoc schemate aut vitia aut virtutes eorum, de quibus loquitur, deformat.

As the painter describes the figures with the colors, so the speaker with this figure represents the vices and virtues of the characters he is speaking about.

Rutilius Lupus follows therefore the definition of Polybius Rhethor. The same applies to the works of Daretes, Malalas, Tzetzes and Isaac, which also must be read in the light of the rhetorical and sophistic tradition that refers to the iconisms and the characteristisms of the ekphrastic discourse. In fact, the mythological portraits of these authors draw attention to other texts, neglected by strictly physiognomic studies, but still deserving to be brought into the discussion in this context. ${ }^{7}$ In the Interpretation of Dreams, Artemidorus notes traces of physiognomy in a dream. In the Onomasticon, Pollux provides the names for the various parts of the body, starting from the head. In the Heroicus, Philostratus offers a series of portraits of mythological characters such as those of Dictys and Daretes. The description of these characters is physiognomic, as it always combines moral nuances with physical characteristics. This Philostratus is the second of the four that are known, the same one who authored the Imagines, a description of a gallery of paintings which also contains various descriptions of mythological characters. Philostratus is one of those leading authors who, much like Dio Chrysostom, loved to add innovations into his mythology and therefore enjoyed dwelling on the physical and moral traits of this or that character, just as Dictys, Daretes, Malalas, Tzetzes and Isaac would more systematically do centuries later. Philostratus, who had already made use of ekphrastic techniques when he wrote the Imagines, uses the same method in his Heroicus for portraits of epic heroes, here focusing particularly on eyebrows, beards, and nose,

7 On the relationship between onomastics, dreams and physiognomy, see Cianci 2014. 
since the ekphrastic technique requires special attention to non-random correlations and canonical rules of description.

Below are some examples from the Heroicus. ${ }^{8}$ In fact, the following series of mythological-physiognomic portraits can be seen as exemplary for Philostratus's ekphrasis of physiognomic features:

\section{Protesilaus (10)}

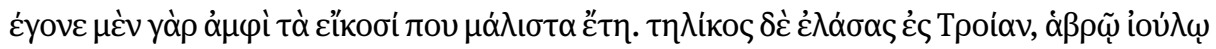

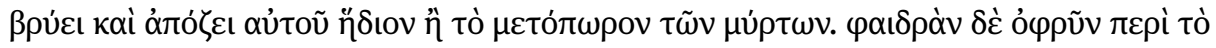

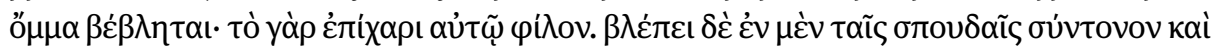

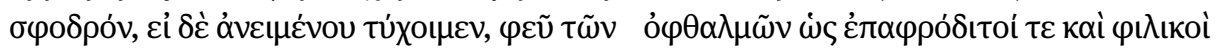

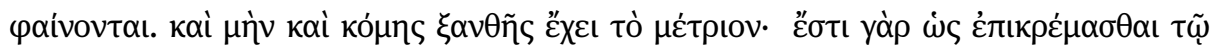

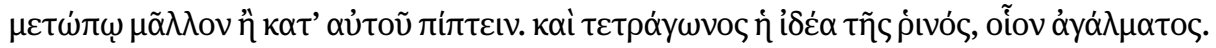

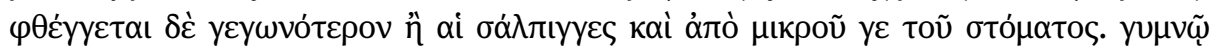

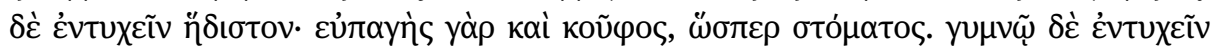

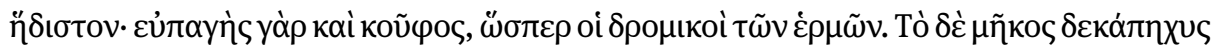

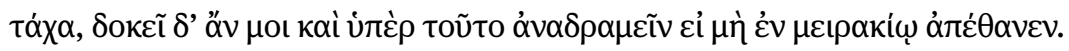

He is about twenty years old at most. Because he sailed to Troy at such a young age, he has a full, splendid beard and smells sweeter than autumn myrtles. Cheerful eyebrows frame his eyes, which gives him a pleasant, friendly manner. When he exerts himself, he looks intense and determined. But if we meet him at ease, ah, how lovely and friendly his eyes appear! He has blond hair of moderate length. It hangs a little over his forehead rather than covering it. The shape of his nose is perfect, like the statue's. His voice is more sonorous than trumpets and comes from a small mouth. It is most enjoyable to meet him naked, since he is well built and nimble, just like the herms set up in race courses. His height is easily ten cubits, and it seems to me that he would have exceeded this had he not died in his early twenties.

\section{Nestor (26)}

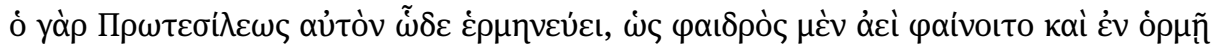

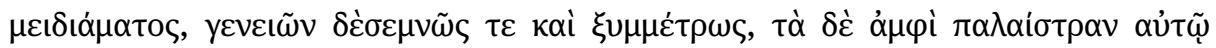

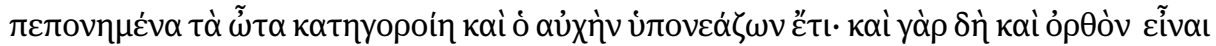

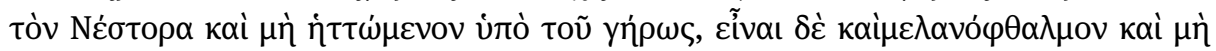

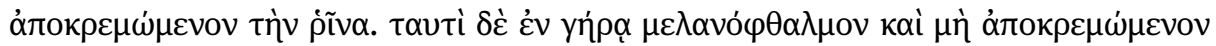

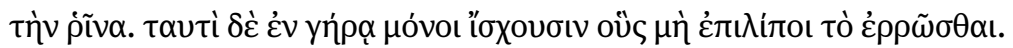

Protesilaus describes him as always appearing cheerful, beginning to smile, and with a beard that is majestic and well-proportioned; his ears display what he went through at wrestling school, and his neck is restored to its strength. In truth, Nestor stands upright, not defeated by old age, with black eyes and without a drooping nose. And this, in old age, only those whom strength has not forsaken maintain.

8 I quote from the transl. by J.K. Berenson Maclean and E. Bradshaw Aitken (2002), with slight changes. 


\section{Antilochus (26)}

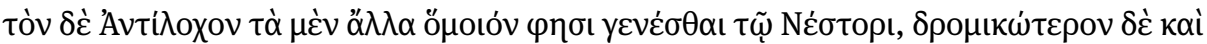

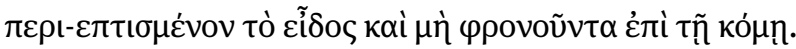

In other respects Antilochus resembled Nestor, but he was swifter, trim in physique, and paid no attention to his hair.

\section{Sthenelus, Diomedes (27)}

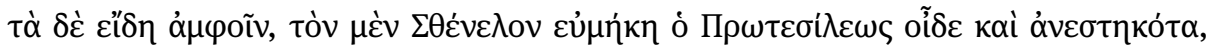

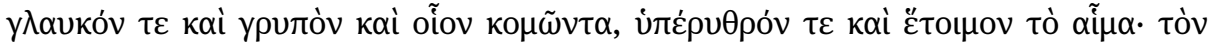

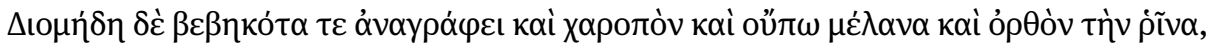

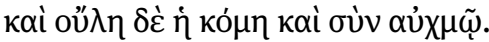

With respect to the appearance of the two men, Protesilaos knows that Sthenelos is of a good size and towering, gray-eyed, with an aquiline nose, fairly long-haired, ruddy, and hot-blooded. He describes Diomedes as steadfast and having eyes that are blue-gray and not black at all and a straight nose; his hair was woolly and dirty.

\section{Philoctetes (28)}

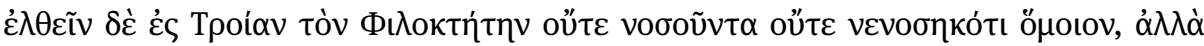

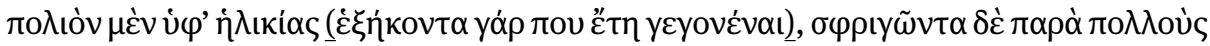

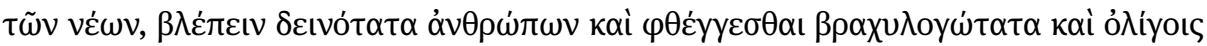
$\tau \tilde{\omega} \nu \beta o v \lambda \varepsilon v \mu \alpha \dot{\tau} \tau \omega \nu \xi u v \tau i \dot{\theta} \varepsilon \sigma \theta \alpha \mathrm{t}$.

When Philoctetes came to Troy, he was neither ill nor like one who had been ill, and although his hair was gray because of age (he was about sixty years old), he was more vigorous than many of the young men, his gaze was most fearsome among mortals, his words most brief, and he attended few of the councils.

\section{Agamennon, Menelaus, Orestes (29)}

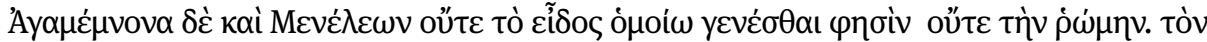

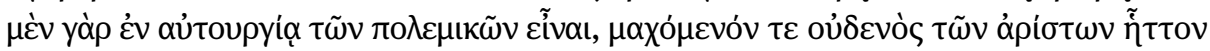

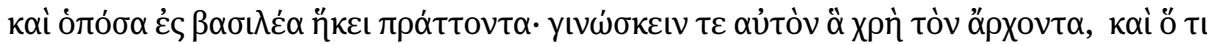

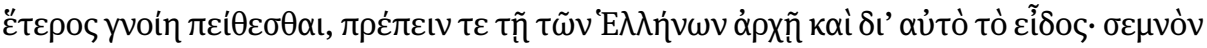

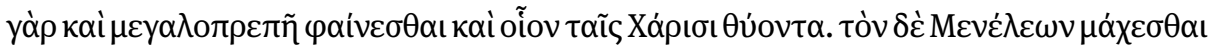

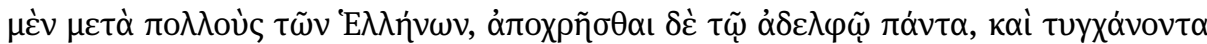

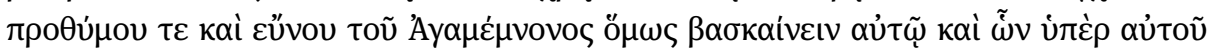

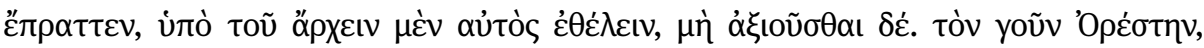




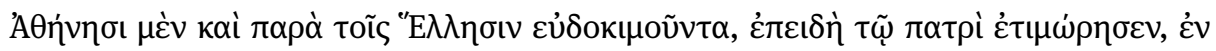

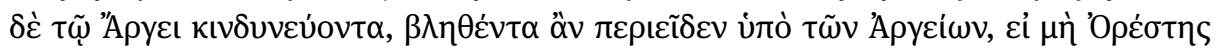

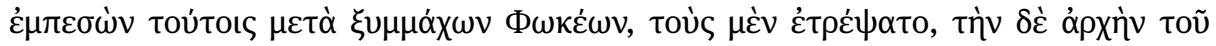

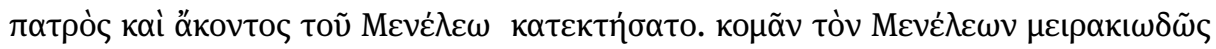

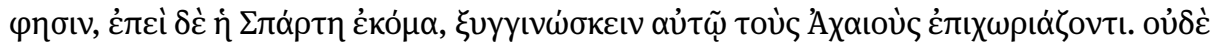

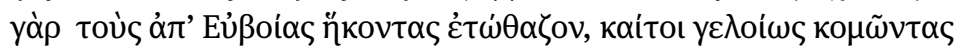

Agamemnon and Menelaus were alike neither in appearance nor strength. Agamemnon was experienced in the arts of war, was inferior to none of the best in combat, and fulfilled all the duties of a king: he knew what was necessary for a ruler, was persuaded by whatever insight someone else had, and even by his very appearance was fit to lead the Greeks. He looked majestic and magnificent and like the sort of person who offered sacrifice to the Graces. But Menelaus, although he fought along with many of the Greeks, abused his brother in every respect. And while having the goodwill and favor of Agamemnon, he nevertheless maligned him and what Agamemnon was doing for him by his desire to rule, even though he was not deemed worthy. Orestes, at any rate, was held in honor in Athens and among the Greeks [...] Menelaus wore his hair boyishly long, as was the Spartan custom, and the Achaeans made allowance for him when he was visiting, since they did not mock those who came from Eubea even though their hair was ridiculously long.

\section{The Locrian Ajax (31)}

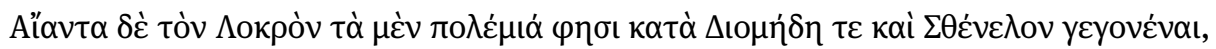

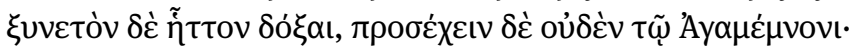

The Locrian Ajax was as capable as Diomedes and Sthenelus in the arts of war, but appeared less intelligent and paid no heed to Agamemnon.

\section{Cheiron (32)}

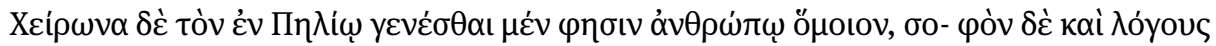

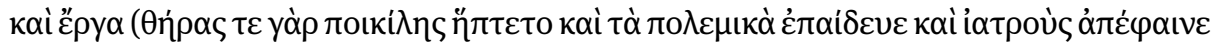

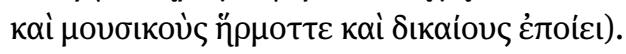

Cheiron, who lives on Mount Pelion, resembled a human and was skilled in words and deeds, for he participated in various kinds of hunts, taught the skills of war, trained physicians, "tuned" the musicians, and made people just.

\section{Palamedes (33)}

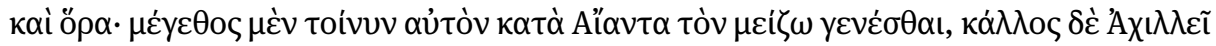

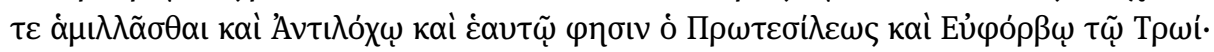

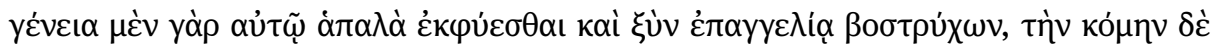




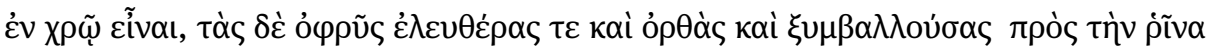

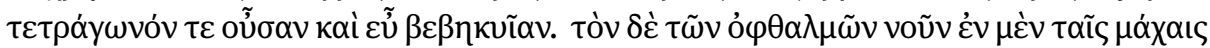

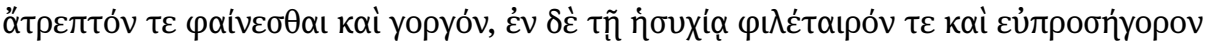

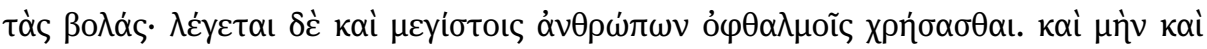

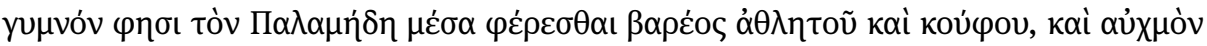

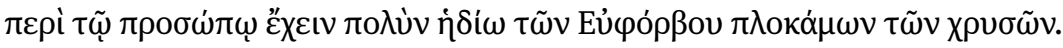

So then in height he was the same as the greater Ajax; in beauty, Protesilaus says, he vied with Achilles, Antilochus, Protesilaus himself, and with the Trojan Euphorbus. His soft beard was springing up and with the promise of curls; his hair was cut close to his skin; his eyebrows were noble, straight, and came together above the nose, which was perfect as a square and stately. The resolve of his eyes appeared unshaken and fierce in battles, but when he was at rest their gaze was full of comradely affection and affable; he also is said to have possessed the most marvelous eyes among mortals. And in truth, Protesilaus also says that when he was naked, Palamedes weighed halfway between an athlete and a lithe person, and that he had a toughness about his face that was much more pleasant than the golden locks of Euphorbus.

\section{Odysseus (34)}

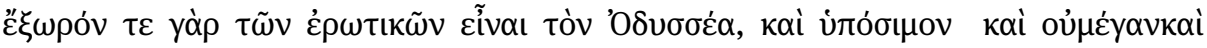

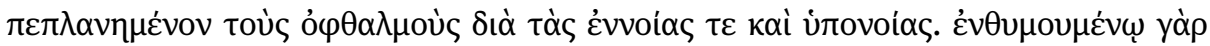

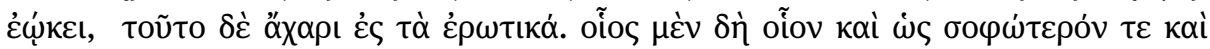

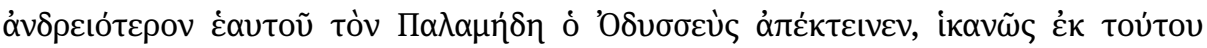

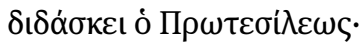

Odysseus was too old for amorous affairs, was somewhat flat-nosed, short, and had shifty eyes because of his schemings and insinuations. He was like one who was always plotting, and this gracelessness extended to his amorous affairs. Therefore, Protesilaus aptly teaches that a man like Odysseus killed a man like Palamedes, who was both more clever and more courageous than he.

\section{Ajax Telamonius (35)}

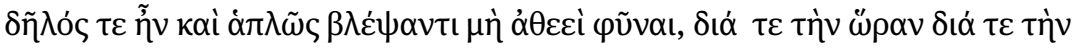

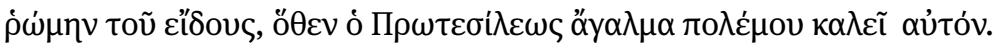

It was absolutely clear to anyone who saw him that he did not grow up without divine aid because of the beauty and strength of his physique. Hence, Protesilaus calls him the very picture of war.

\section{Teucer (36)}

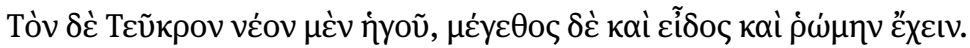




\section{Hector (37)}

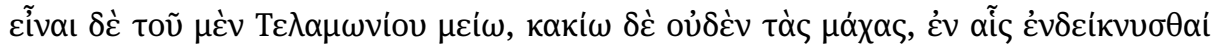

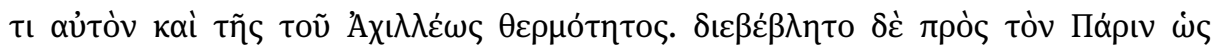

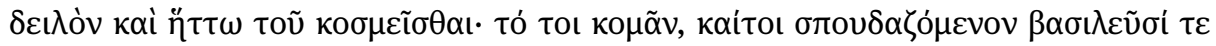

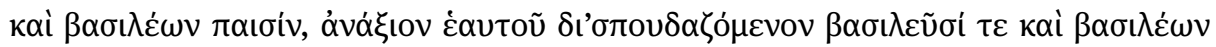

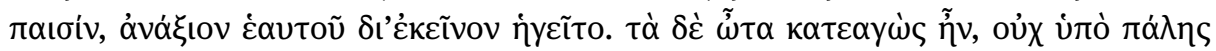

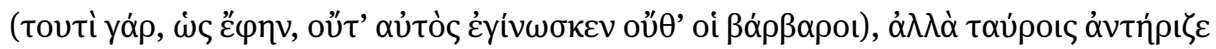

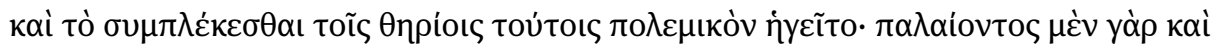

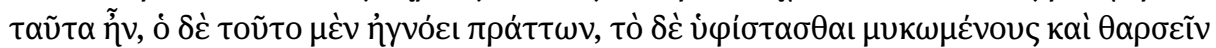

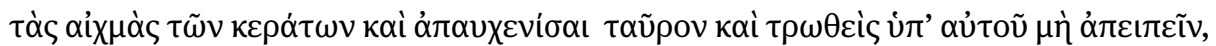

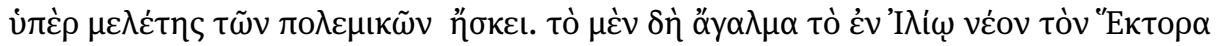

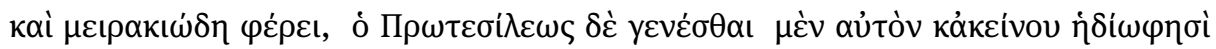

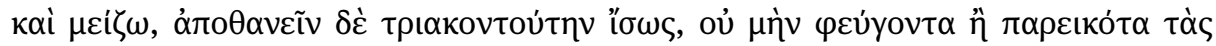

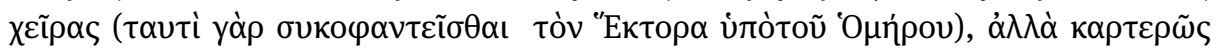

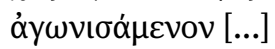

He was smaller than the son of Telamonius, but not at all inferior in fighting, in which he displayed something even of the heat of Achilles. He was filled with resentment against Paris as a coward and as one who gave in to self-adornment. In truth, Hector thought that to have long hair, even though it is treated with respect by princes and the children of princes, was despicable for himself because of that man. His ears were damaged, not by wrestling (for this sport, as I said, neither he nor the barbarians knew), but he fought against bulls and considered engagement with such beasts warlike. These activities also are a part of wrestling, but when he did them, he was ignorant of this sport, and for military exercise he practiced submitting to bellowing bulls, having no fear of the points of their horns, taming a bull by forcing back its neck, and not giving up, even though he was wounded by it. The statue in Ilion indeed presents Hector as young and boyish, but Protesilaus says that he was more pleasant and larger than that statue. He died probably at the age of thirty, and he surely did not flee or let his hands drop idly (for in these matters Hector is slandered by Homer). Rather he fought mightily [...]

\section{Aeneas (38)}

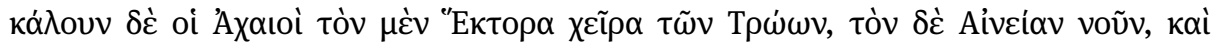

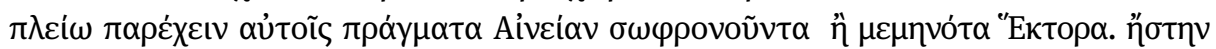

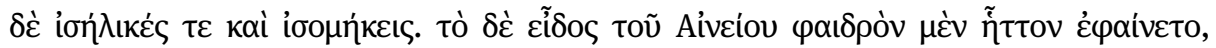

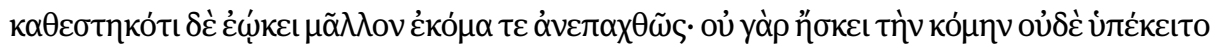

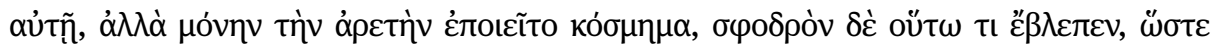

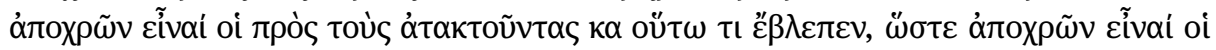

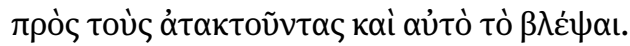

While the Achaeans called Hector the hand of the Trojans, they called Aeneas the mind. He presented matters to them more prudently than did the madly raging Hector. They were both of the same age and 
height, and although Aeneas's appearance seemed less radiant, he resembled Hector more when that man had settled down, and he wore his hair long without offense. He did not adorn his hair, nor was he enslaved to it. Instead, he made virtue alone his adornment, and he looked at things so vehemently that even his glance itself was sufficient against the unruly.

\section{Paris (40)}

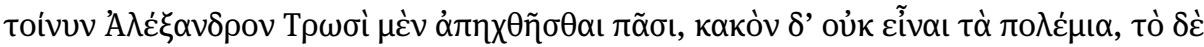

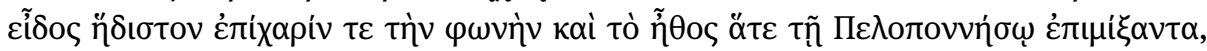

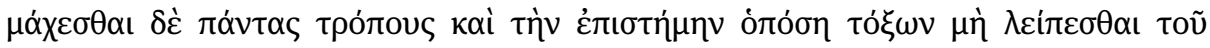

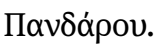

Alexander was hated by all the Trojans, but he was not worthless in the business of war; his appearance was most pleasing, and his voice and character were charming inasmuch as he had dealings with the Peloponnesus. He could fight in all ways and, as far as knowledge of bows is concerned, he did not fall short of Pandarus.

\section{Achilles (48)}

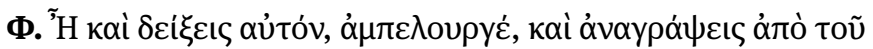

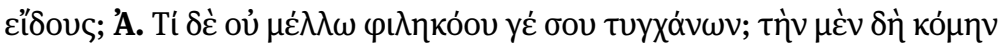

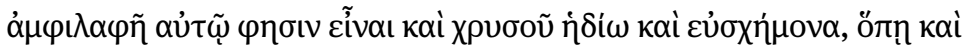

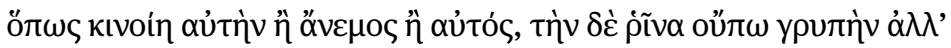

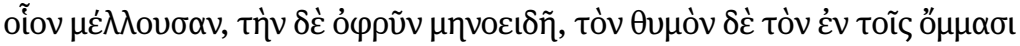

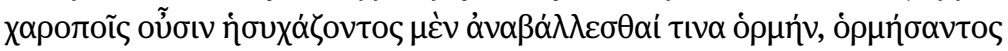

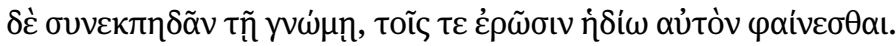

P. Will you portray Achilles, vinedresser, and describe him from his appearance? V. Why shouldn't I, since I have met you who are so fond of listening? Protesilaus says that Achilles's hair is thick, lovelier than gold, and becoming no matter where and how either the wind or he himself may move it. His nose is not quite aquiline, but almost so; his brow is crescent-shaped. The spirit in his eyes, which are bluish-gray, casts off a certain eagerness even when he is still; when he is rushing on, they spring out along with his purpose, and then he seems more lovely than ever to those who cherish him.

\section{Patroclus (49)}

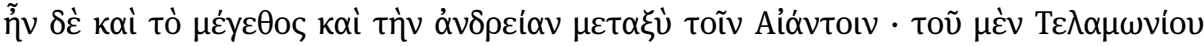

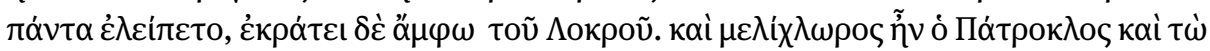

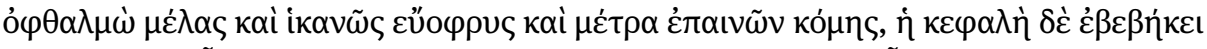

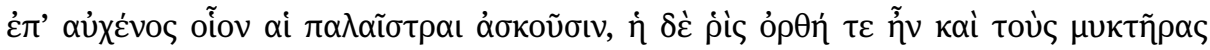

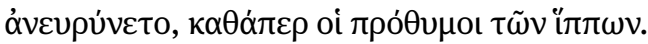


In size and bravery he was between the two Ajaxes. He fell short of the son of Telamonius in all things, but he surpassed both the size and bravery of the Locrius. Patroclus had an olive complexion, black eyes, and sufficiently fine eyebrows, and he commended moderately long hair. His head stood upon his neck as the wrestling schools cultivate. His nose was straight, and he flared his nostrils as eager horses do.

\section{Neoptolemus (52)}

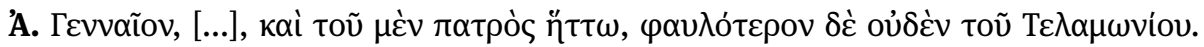

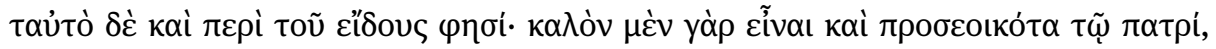

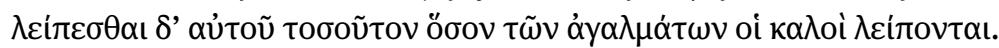

He was noble [...], and, although inferior to his father, was in no way more ordinary than Telamonius. Protesilaus says the same thing about his appearance as well: he was good-looking and resembled his father, but was inferior to him in the same way that beautiful people are inferior to their statues.

\section{Examples of iconisms and characterisms in the Homeric poems}

Going back to the origins, we know that the first physiognomist was Homer - the protos heuretes - as Evans suggests, and a description such as the one of the ugly Thersites confirms this, although Thersites is not the only hero described in this kind of rudimentary physiognomy. Another ugly character destined for a bad ending is Dolon, for whom the specific phrase "bad looking” (Il. 10.314) is used. Pasquali also notes that Homer describes Menelaus, for example, as $\xi \alpha v \theta$ ó ("blond”), in a predominantly brown-haired population. Also, more generally, it is known that in both poems there is a continual reference to different parts of the human body:

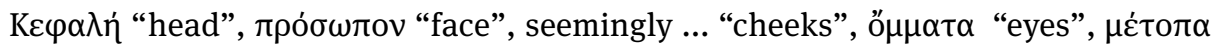
"front" and so on. There are two other physiognomic descriptions in Homer of particular interest. The first is the teichoscopy, i.e. the "viewing from the wall" (Il. $3.166 \mathrm{~s}$.); the second is inserted in the same scene, as a physical description based on Antenor's remembrance: an embassy to Troy by Menelaus and Odysseus. When Priamus invites Helen, on the top of the walls of Troy, to tell her who the main heroes were, the first to be indicated - Agamemnon - is a majestic, noble man.

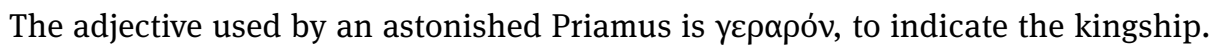
The other one, shorter than Agamemnon (also a significant comparison, which in some cases will be found in later portraits) also has broad shoulders and chest: this one is Odysseus. Also Ajax is tall and has broad shoulders. In the Homeric teichoscopy we can see that: 
1) The body is described in terms of size;

2) Speculative thoughts on the body go side by side with thoughts on the character.

Homer, according to the memories of Antenor, offers a comparison between Menelaus and Odysseus: Menelaus towers over Odysseus, but when they are seated, the one prevailing is Odysseus and not because of any physical characteristic, but rather because of his eloquence:

\footnotetext{
"But when the mighty voice from the chest played out of dense words like winter flakes with Odysseus no one would be in a competition

we were no longer as surprised for him as before, for his appearance" (Il. 3.221-224).
}

The astonishing outward aspect of Odysseus is described just a few lines before, when he

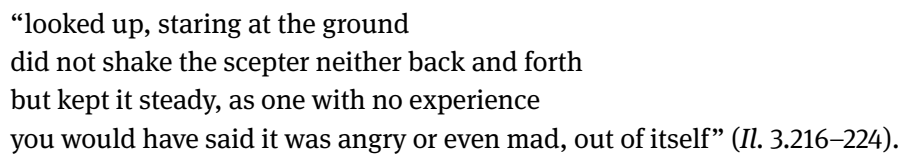

This episode presents us with a really new idea in a heroic setting: even those who do not have the "physique du role" can still achieve bold, heroic results. This represents our first critical hint of a point of view that is opposed to the aristocratic cliché of kaloskagathos. In the Odyssey, the first 'anti-heroic' speech about the relativity of beauty is put into the mouth of Odysseus, who emphasizes that good looks do not always line up with intelligence:

\begin{abstract}
"Certainly the gods do not give gracious gifts to all men alike / they do not give them beauty, nor sense, nor eloquent word. / One is weaker in appearance / but a god of beauty crowns his saying; and everyone looks at him / fascinated: he speaks safely / with sweet kindness; he shines in the meetings, and when he comes around the city, people look at him as a god. / Yet another one says 'he's as handsome as a god, but his words do not have a crown of grace. So you have shining beauty: nothing better / a god could create: but you have an empty mind" (Od. 8.167-179).
\end{abstract}

The same considerations hold for his wife Penelope:

\footnotetext{
"How would you know, foreigner, whether I am superior to other women or not, as to wisdom and good advice?” (Od. 19.325-326).
}

Penelope is the first heroine who declares herself superior to other women not for her beauty but for her wisdom. If we gather up even a short list of descriptions of the heroes and heroines described in the Iliad and in the Odyssey, we notice that Homer was indeed interested in the details of the body. To give some idea of this, let me provide an overview of the descriptions of Hector. 


\section{Moral and general Features}

\section{Beauty}

Il. 17.142

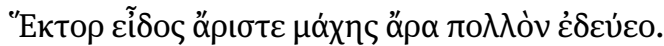

Hector, you're the best, but very weak in the battle.

Il. $12.462-463$

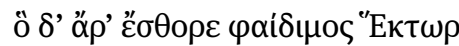

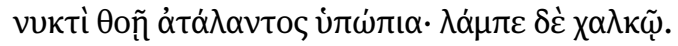

She immerses herself in the splendid Hector as night leaving / suddenly seeing it; he shone in bronze.

\section{Arrogance}

Il. 15.440

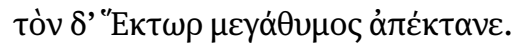

He was killed by the superb Hector.

\section{Physical Features}

\section{Hair}

Il. 22.401-403

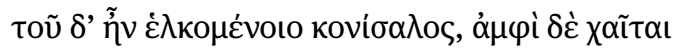

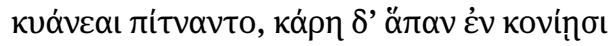

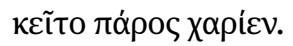

around him, dragged, the dust rose up;

his black hairs were spread around, her

beautiful head was surrounded by the dust.

\section{Eyes}

Il. 12.466

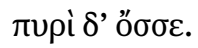

the eyes of fire

\section{Skin}

Il. 11.351-352

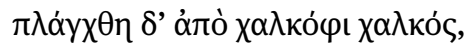

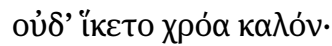


But bronze was made from bronze itself

Nor did it reach the beautiful skin.

It is clear how the moral features of the hero are inferred from his physical characteristics, according to the method that will be followed many centuries later by the rhetorical and physiognomic disciplines. Among the parts of the body to which Homer draws our attention, the hands and the feet are the most important. The relationship between the parts of the body at the crucial moment of the funeral is also particularly important, as in the cases of the scratched face (Il.11.393), the pulled hair (II. 22.405), and the head of the corpse in the hands of a relative (Il. 24.724).

\section{Characterisms and iconisms in the portraits of Daretes, Tzetzes, Malalas and Isaac Porphyrogenitus}

Synopsis

\section{Daretes}

30 Characters

24 Male; 6 Female

16 Greeks; 8 Trojans

1 Greek; 5 Trojans

\begin{tabular}{llll}
\hline Greeks & Greeks & Trojans & Trojans \\
\hline Achilles & Helen & Antenor & Andromache \\
\hline Agamennon & Deiphobus & Briseis \\
\hline Ajax Locrius & Helen & Cassandra \\
\hline Ajax Telamonius & Aeneas & Hecuba \\
\hline Castor & Hector & Polyxena \\
\hline Diomedes & Paris Alexander & \\
\hline Macaon & Priamus & \\
\hline Menalaus & Troilus & \\
\hline Merion & & \\
\hline Nestor & & \\
\hline Neoptolemus & & \\
\hline
\end{tabular}




\section{Odysseus}

Palamedes

Podalirius

Pollux

Protesilaus

\begin{tabular}{llll}
\hline 16 & 1 & 8 & 5 \\
\hline
\end{tabular}

\section{Malalas}

Chronographia

\section{Characters}

26 Male; 8 Female

17 Greeks; 9 Trojans

3 Greeks; 5 Trojans

\begin{tabular}{|c|c|c|c|}
\hline Greeks & Greeks & Trojans & Trojans \\
\hline Achilles & Diomeda & Antenor & Andromache \\
\hline Agamennon & Helen & Deiphobus & Cassandra \\
\hline Ajax Lorius & Phaedra & Helen & Chryseis \\
\hline Ajax Telamonius & & Aeneas & Hecuba \\
\hline Chalcas & & Hector & Polyxena \\
\hline Diomedes & & Glaucus & \\
\hline Philoctetes & & Parise & \\
\hline Idomeneus & & Priamus & \\
\hline Hyppolytus & & Troilus & \\
\hline \multicolumn{4}{|l|}{ Menelaus } \\
\hline \multicolumn{4}{|l|}{ Merion } \\
\hline \multicolumn{4}{|l|}{ Neoptolemus } \\
\hline \multicolumn{4}{|l|}{ Nestor } \\
\hline \multicolumn{4}{|l|}{ Odysseus } \\
\hline \multicolumn{4}{|l|}{ Palamedes } \\
\hline \multicolumn{4}{|l|}{ Patroclus } \\
\hline \multicolumn{4}{|l|}{ Protesilaus } \\
\hline 17 & 3 & 9 & 5 \\
\hline
\end{tabular}


The characters taken into account in this chapter are those portrayed by Daretes, Malalas, Tzetzes, Isaac, as well as the ones described in anonymous Roman mythography. They show a special physiognomy attitude, since these texts are particularly interested in the portraits of people and the mythological world. Overall, there are 51 portraits, almost all of them drawn from the stories related to the Trojan War, and almost all of them mentioned by Homer, except Palamedes and Polyxena, Phaedra and Hyppolytus. Malalas presents 24 portraits, but since Thurn (2000) takes ten additional portraits from Isaac (from Agamemnon to Palamedes), imagining a gap in Malalas's manuscript, the number of portraits by Malalas grows to 34, which is the largest gallery of portraits we have. If we exclude this integration of ten more portraits, the largest number of portraits is to be found in the work of Daretes. In every description the cataloguing of the characters follows thus two mythological criteria:

1) the importance of the role and

2) kinship;

This criterion promotes and emphasizes couples and groups. For example, the Atrids appear in couples, with the children coming in order of importance after their parents; for the Trojan deployment Priamus has a sort of fixed primacy, and among his sons Hector is the best one.

Among the characters of Daretes, the one who excels all others is Helen with her brothers Castor and Pollux. Another professional couple is that of the two Greek doctors, Podalirius and Macaon, who were already presented in pairs by Homer. Briseis the slave appears only in Daretes and in the Prolegomena to Tzetzes's Allegoriae Iliadis. In Daretes, Helena plays a strategic role, because she closes the gallery of De excidio Troiae balancing, eventually, the role she had at the beginning. From the series of Malalas's characters, a clear preference for Greek male heroes surfaces. Among the innovations, the presence of Hippolytus and a "wise" Phaedra are noteworthy. With respect to the royal family, Malalas's scheme is basically accurate:

- male component: Priamus (king), Hector (the first child in importance), Deiphobus and Helenus (brothers-in-law, always associated with each other, Helenus has the talent of forecasting the future).

- female component: Hecuba (queen), Andromache (wife of Hector) Cassandra (Helen's twin, who also has the ability to predict the future), Polyxena (the younger daughter).

Regarding the Greek women, Helen, the favourite, the first lady, is associated with Diomeda, a kind of "Briseis". Although it is not attested in other sources, there is a woman from Lesbos, the daughter of the king Phorbales, who becomes a solace for Achilles, after he was deprived of his favorite slave.

The Trojan women mentioned are the same ones that we find in Isaac: Andromache, Cassandra, Hecuba and Polyxena. The only innovation is Astynome Chryseis, who is also described by Tzetzes, in his Prolegomena to the Allegoriae Iliadis. 
As to Tzetzes, four works should be considered: Allegoriae Iliadis, Antehomerica, Homerica, and Posthomerica. The most interesting, from the point of view of physiognomic ekphraseis, are the Allegoriae Iliadis, which gather a gallery of characters. Tzetzes also shows a preference for the Greek male heroes. The portrait of Alcestis's son, Eumelus, son of "the best among the mothers" is also interesting. Tzetzes describes only one ugly homeric figure, Thersites, forgotten by all the other authors, but present in the anonymous mythologic "operetta" of the Uffenbachian library, which was probably inspired by Allegoriae Iliadis.

In Isaac's work there is the usual prevalence of Greek male heroes (16 versus 7), but the originality of this text lies in the narrative structure: digression, exordium, and invocation of the final divinity. Noteworthy is the absence of any major female character such as Helen. The women described are the usual four Trojans, in the usual sequence (Hecuba, Andromache, Cassandra, and Polyxena).

The anonymous mythological "operetta" ignores women. The portraits concern only male heroes, of which 13 are Greek and only one Trojan, the only one who is indispensable because he is the best: Hector.

\section{Tzetzes}

Allegoriae Iliadis, Prolegomena

30 Characters

24 Male; 6 Female

4 Greeks; 2 Trojans

22 Greeks; 2 Trojans

\begin{tabular}{llll}
\hline Greeks & Greeks & Trojans & Trojans \\
\hline Achilles & Diomeda & Aeneas & Astunome Chryseis \\
\hline Agamennon & Helen & Hector & Briseis (Hippodamia) \\
\hline Antilochus & Laodamia & & \\
\hline Ajax Locrius & Tecmessa & & \\
\hline Ajax Telamonius & & \\
\hline Chalcas & & \\
\hline Diomedes & & \\
\hline Eumelus & & \\
\hline Eurialus & & \\
\hline Phoenix & & \\
\hline Idomeneus & & \\
\hline
\end{tabular}




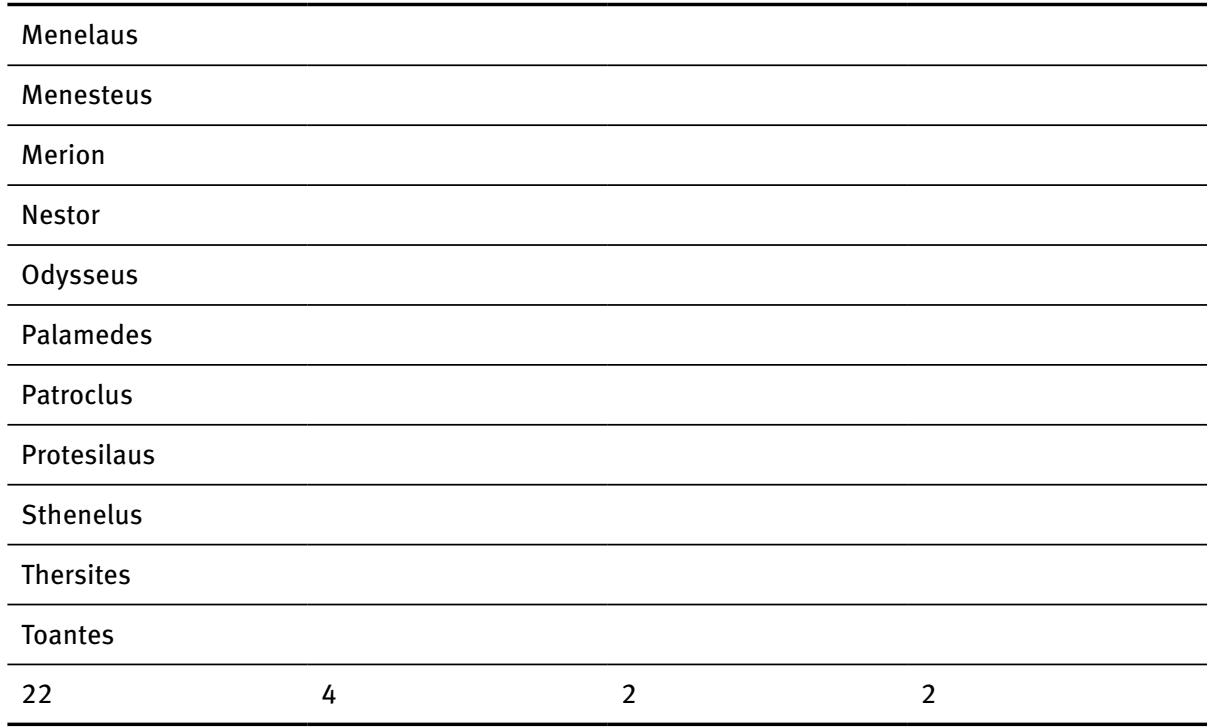

\section{Tzetzes}

Antehomerica

\section{Characters}

1 Male; 1 Female

1 Greek

1 Greek

\begin{tabular}{llll}
\hline Greeks & Greeks & Trojans & Trojans \\
\hline Protesilaus & Helen & & \\
\hline 1 & 1 & 0 & 0 \\
\hline
\end{tabular}

Tzetzes

Homerica

1 Character

1 Trojan

\begin{tabular}{|c|c|c|c|}
\hline Greeks & Greeks & Trojans & Trojans \\
\hline \multicolumn{4}{|c|}{ Hector } \\
\hline & & 1 & \\
\hline
\end{tabular}




\section{Tzetzes}

Posthomerica

15 Characters

11 Male; 4 Female

4 Greeks; 7 Trojans

4 Trojan women

\begin{tabular}{|c|c|c|c|}
\hline Greeks & Greeks & Trojans & Trojans \\
\hline Agamennon & & Antenor & Andromache \\
\hline Philoctetes & & Deiphobus & Cassandra \\
\hline Neoptolemus & & Helenus & Hecuba \\
\hline \multirow[t]{4}{*}{ Nestor } & & Aeneas & Polyxena \\
\hline & & Glaucus & \\
\hline & & Priamus & \\
\hline & & Troilus & \\
\hline 4 & 0 & 7 & 4 \\
\hline
\end{tabular}

\section{Anonymus}

Antehomerica Uffenbachiana

14 Characters

14 Male; 0 Female

13 Greeks

1 Trojan

\begin{tabular}{|c|c|c|c|}
\hline Greeks & Greeks & Trojans & Trojans \\
\hline Achilles & & Hector & \\
\hline \multicolumn{4}{|c|}{ Ajax Locrius } \\
\hline \multicolumn{4}{|c|}{ Ajax Telamonius } \\
\hline \multicolumn{4}{|c|}{ Antilochus } \\
\hline \multicolumn{4}{|l|}{ Chalcas } \\
\hline \multicolumn{4}{|c|}{ Diomedes } \\
\hline \multicolumn{4}{|c|}{ Philoctetes } \\
\hline Nestor & & & \\
\hline
\end{tabular}


Nireus

Odysseus

Palamedes

Protesilaus

Thersites

$\begin{array}{llll}13 & 0 & 1 & 0\end{array}$

\section{Isaac Porphyrogenitus}

27 Characters

23 Male; 4 Female

16 Greeks; 7 Trojans

4 Trojan women

\begin{tabular}{|c|c|c|c|}
\hline Greeks & Greeks & Trojans & Trojans \\
\hline Achilles & & Antenor & Andromache \\
\hline Agamennon & & Deiphobus & Cassandra \\
\hline Ajax Locrius & & Aeneas & Hecuba \\
\hline Ajax Telamonius & & Helenus & Polyxena \\
\hline Chalcas & & Hector & \\
\hline Diomedes & & Priamus & \\
\hline Philoctetes & & Troilus & \\
\hline \multicolumn{4}{|l|}{ Idomeneus } \\
\hline \multicolumn{4}{|l|}{ Menelaus } \\
\hline \multicolumn{4}{|l|}{ Merion } \\
\hline \multicolumn{4}{|l|}{$\begin{array}{l}\text { Neoptolemus } \\
\text { (Pyrrhus) }\end{array}$} \\
\hline \multicolumn{4}{|l|}{ Nestor } \\
\hline \multicolumn{4}{|l|}{ Odysseus } \\
\hline \multicolumn{4}{|l|}{ Palamedes } \\
\hline \multicolumn{4}{|l|}{ Patroclus } \\
\hline \multicolumn{4}{|l|}{ Protesilaus } \\
\hline 16 & 0 & 7 & 4 \\
\hline
\end{tabular}




\section{Bibliography}

Berenson Maclean, J. K., and B. Aitken 2002. Flavius Philostratus, On Heroes, Atlanta 2002.

Boissonade, J. F. (ed.) 1851. Tzetzae Allegoriae lliadis. Accedunt Pselli Allegoriae. Quarum una inedita. Hildesheim 1967 (1st ed. Paris 1851).

Browning, R. 1975. “Homer in Byzantium”. In: Viator 6, 15-33.

Cianci, D. 2014. Corpi di parole. Descrizione e fisiognomica nella cultura greca. Pisa.

Dederich, A. (ed.) 1833. Dictys Cretensis sive Lucii Septimii Ephemeridos belli Troiani libri sex. Bonnae.

Eisenhut, W. (ed.) 1973. Dictys Cretensis Ephemeridos Belli Troiani libri a Lucio Settimio ex graeco in latinum sermonem translati. Accedunt Papyri Dictys Graeci in Aegypto inventae. Leipzig.

Foerster, R. (ed.) 1893. Scriptores Physiognomonici Graeci et Latini, I-II. Lipsiae.

Haury, J. 1900. “Johannes Malalas identisch mit dem Patrarchen Johannes Scholastikos?”. In: Byzantinische Zeitschrift 9, 337-356.

Hinck, H. (ed.) 1873. Polemonis Declamationes quae exstant duae. Leipzig, 57-88.

Huhn, F., and E. Bethe 1917. "Philostratus Heroicus und Dictys". In: Hermes 52, 613-624.

lacobs, F. (ed.) 1793. Ioannis Tzetzae Antehomerica, Homerica et Posthomerica, Lipsiae (reprinted Osnabrück 1972).

Kazdan, A. 1991. “Komnenos, Isaac the Porphirogennetos”. In: The Oxford Dictionary of Byzantium II. Oxford, 1146.

Kinstrand, J. F. (ed.) 1979. Isaac Porphyrogenitus. Praefatio in Homerum. Uppsala.

Lapini, W. 1997. “I libri dell’Ephemeris di Ditti- Settimio”. In: Zeitschrift für Papyrologie und Epigraphik 117, 85-89.

Meister, F. (ed.) 1873. Dictys, Daretis Phrygii. De Excidio Troiae Historia. Leipzig.

Patzig, E. 1892. "Dictys Cretensis”. In: Byzantinische Zeitschrift 1, 131-152.

Patzig, E. 1901. "Malalas und Tzetzes". In: Byzantinische Zeitschrift 10, 385-393.

Pontani, F. 2007. "The first Byzantine Commentary on the Iliad: Isaac Porphyrogenitus and his scholia”. In: Byzantinische Zeitschrift 99/2, 559-604.

Pontani, F. 2005. Sguardi su Ulisse. La tradizione esegetica greca all'Odissea. Rome.

Spengel, L. (ed.) 1856. Rhetores graeci, vol. III. Leipzig.

Sophocles, E. A. 1914. Greek lexicon of the Roman and the Byzantine Periods (from B.C. 146 to A.D. 1100), I.II. Cambridge, MA.

Swain, S. (ed.) 2007. Seeing the Face, Seeing the Soul: Polemon's Physiognomy from Classical Antiquity to Medieval Islam. Oxford.

Thurn, I. (ed.) 2000. Ioannis Malalas, Cronographia, Berlin. 
